\title{
Translating and Representing 'The Aftermath of Daesh': A Rhetorical Semiotic Study of Some Mosuli Artists’ Works
}

\author{
Ismail Abdulwahhab Ismail ${ }^{1}$ \\ ${ }^{1}$ Translation Department, Al-Mamon University College , Baghdad , Iraq \\ Correspondence: Translation Department, Al-Mamon University College, Baghdad, 14th Ramadhan, Iraq. \\ E-mail: ismail.a.ismail@almamonuc.edu.iq
}

Received: March 15, 2019 Accepted: April 19, 2019 Online Published: May 23, 2019

doi:10.5539/ells.v9n2p33 URL: https://doi.org/10.5539/ells.v9n2p33

\begin{abstract}
Daesh has profoundly affected the psychological statues of Iraqis; they sacrificed thousands of souls and martyrs to liberate their country from a savage enemy. This study has, therefore, a psychological perspective. It tackles the reflections of agony, suffering and poverty in the behaviour of the artists, writers and translators.

Iraqi artists have represented their suffering and pains in their paintings. They encoded the symbols, colours and semiotic mosaics in association with rhetorical connotations.

Mosul is the city most affected by the terrorist acts during the war. Therefore, the study has selected four Mosuli artists who drew, painted and visually documented that period. Translation does not limit itself to the study and analysis of verbal/linguistic texts; it also tackles the extra-linguistic signs and codes of the source language to transfer them into the target language appropriately and in a way that seems intelligible to the readers or the spectators of these paintings.

The research questions are based on a set of issues: Are the teachers of translation able to construct a bridge between Iraqi society, European society and other societies? These paintings have socio-cultural symbols specific to Iraqi society. Are the teachers of translation able to come out from the shell of the linguistic texts and move towards the semiotic and visual texts?
\end{abstract}

Keywords: the aftermath of Daesh, rhetoric, semiotics, translation and representation

\section{Introduction}

It is undeniable that the period of Daesh was harmful and caused many humanitarian disasters. People have been displaced and have felt of humiliation. The terrorist groups of ISIL have punished innocent men and set out their severe acts - or what is the so-called 'the rule of God' - as a justification to blackmail and oppress people.

After the setback of the Mosul occupation in 2014, people felt frustration and despair over their ruling government. A year since that setback, Mosul and other Arab Sunni ISIS-controlled places witnessed a set of complexities such as poverty, lack of educational facilities and deconstruction of precious antiquities.

Their acts were doubtful and not understandable. Their seemingly crazy and senseless acts reflected a lot of agony in the contemporary history of all Iraqis. In the south, people have been recruited to fight Daesh. In the middle, ISIS has enslaved the oppressed people. Kurds in the north tried to protect themselves and gave a lot of souls. It is of fact to say that the Yazidi minority was the worst affected among the others: their villages were looted and their women were raped. The entire story of ISIL is a sort of Hollywood scenario or a film dedicated to show the audience the history of the Middle Ages wars.

A painting is mostly defined as a reflection and a discharge of emotions. Modern and impressionist works are mirrors of the inner worlds of the artists (Machotka, 2012). The outcome products are imprinted by the consciousness of the drawer. For this reason, the study has selected the visual works of four Mosuli artists to analyse their semiotic and rhetorical values.

Anwar Aldaweesh, Adheed Tarik, Bayt Mar'ee and Khulaif Mahmood, who lived and spent three years under the capture of ISIL provide the data for this study. The scope of analysis is restricted to the role of translation and its effect of transferring impressionist signs and visual reflections of the artists' experiences. Translation is a bridge between two cultures; it transfers what is specific in the source society into the target society. Its role is to give 
the target global societies valuable ideas about the pains and sufferings in the source Iraqi society and to inform them of our catastrophe (Manetti, 1993, p. 49).

Teachers of translations are mostly academic professors with the competence of teaching and guiding their students to realize visual implications and semiotic signs with their deep significations (Brown, 2011). Therefore, this study conducted a pilot study to evaluate teachers' artistic competence in decoding the rhetoric, semiotics and visual pragmatics in the selected works of the Mosuli artists. Three assistant professors who are specialists in translation are the study's experts.

\section{Literature Review}

\subsection{Translation \& Translation Intercultural Competence}

Translation requires a specific artistic and aesthetic competence. Though some academicians regard translation a betrayal of the source text, a skilful translator is actually a communicator between two societies through the process of translation. A message would be perceived for the real intention of communication (Parmentier, 2014).

Translation is, as Parmentier (ibid) argues, a sort of self-translation, which is a different perspective of translation. The mediating processes of translation and self-translation involve transferring the original signs into the target culture. A translator is a mediator between two versions: he must know and realize not only two languages but also two divergent cultures. The mediation between the original artistic work and the target one requires some modifications to make the outcome of translation accord with the target culture and target social systems.

There are many reasons for which authors or artists can decide to translate their works. Wars and conflicts obligated some artists to leave their own country and to live in exile where they acquire a new language, a new experience, a new different culture and in the end, they started to write or draw about that new experience (Rita, 2009, p. 186)

Translation is not only a conversion of linguistic units, as translators must narrow the gap between two cultures. As Nida (1995, p. 118) once said, 'Understanding two cultures is more beneficial than knowing two languages, because meaningful words are effective in a particular cultural background'. Nida's words have been verified with all the history of translation and can be shown in many examples. As painting is an ideal example of culture, translation requires a competent translator to allow the first culture to be transmitted into the second culture. A painting is an unconscious way of self-expression (Myers, 2002, p. 21).

The Mosuli artists have embedded their cultural and social experience of life under the capture of ISIS within their portraits. The need to draw such objects is to display their suffering to the world. This mission requires a translator who can facilitate that display by creating explanations of the cultural background and the significations of semiotic elements in the artistic works that are associated with rhetorical messages.

Students and teachers of translation should master 'intercultural competence'. This term has been widely discussed by Byram and Risager (1999), who have argued that translation students need to master intercultural communication from a communicative perspective; Byram and Risager (1999, p. 58) state that being 'a mediator between cultures' is the ability to mediate between two cultures in effective communication, which is an essential component of intercultural competence.

Regarding intercultural competence, the translator shall choose the communicative translation; as an act of intercultural and artistic communication. A text/picture produced for readers/viewers in a particular social context is rendered for readers/viewers in another context (Olk, 2014). The role of students and translation teachers is to be intercultural mediators as follows:

- $\quad$ Relating and identifying the specificity in the source and the target cultures.

- Explaining the source culture in terms of the target one, i.e., the translator tries to create a mediating position for divergences in the two cultures (Olk, 2014, p. 13)

Accordingly, first, the role of the mediator translator is to explain the social and cultural contexts in the period of ISIS and how it is reflected into semiotic and painted signs. Second, the target recipient should receive the feelings and the visual messages of the artist in an accurate and easy way.

\subsection{The Semiotic Representations of 'the Aftermath of Daesh'}

The importance of semiotics is its acknowledgement that the representation of the signs in the visual works and paintings is dynamic, i.e., the significance of the painting is not understood in isolation. It is instead a result of complex relations between the translators, the signs in the paintings and other factors, such as society and culture 
(Curtin, 2016, p. 51). This means the translator is part of the process of representing the socio-cultural background of the signs.

This holistic view of signs accords with the definition provided by Eco (1976, p. 16): a sign is an entity referring to something else. Therefore, semiotics is concerned with how this reference is related to the established social conventions.

A painting of Anwar Darweesh, for instance, can have varying interpretations depending on where and how that painting is seen. Potts $(1996$, p. 20) states that artistic works are completely activated by cultural conventions. Peirce (as cited in Curtin, 2016, pp. 51-68) classifies signs into iconic, indexical and symbolic:

1) An iconic sign links a signifier with a signified through the compatibility in appearance.

2) An indexical sign has been defined as the replacement of a visible sign for an invisible one, e.g., 'SMOKE refers to FIRE, A BULLET HOLE indicates a particular ACTION or TEARS denote SADNESS.

3) Unlike the iconic or indexical sign, symbolic signs combine the signifier and the signified in a conventional manner. The linkage is not logical or physical, but it is taught socially like dollar signs (money) or flag (country).

An example is an abstract painting or portrait in a black colour. If the painting is black, then it refers to the colour black (iconic) and can be conceptualized differently: darkness, pessimism and sadness (symbolic), or the colour of smoke (indexical).

Most of the paintings created after the occupation of ISIS are associated with the signs of war: broken bricks and red colour for blood. Black colour was dominant due to the dark period. The Mosuli artists have employed the above-mentioned three types of signs - iconic, indexical and symbolic - to reveal their agony.

\subsection{Visual Culture, Pragmatics and Rhetoric in the Paintings}

The paintings of the Iraqi artists are a visual version of Iraqi socio-cultural conditions. Therefore, it is necessary to focus on the methods of representing that culture visually with its rhetorical and pragmatic implications.

A painting is the perfect example of visual culture. The field of visual culture has been tackled in other subjects, such as history of art, critical theory, media studies, anthropology and cultural studies (Nicholas, 2011). It seems that the culture represented and expressed in a painting should be linked to the rhetoric (visual rhetoric) because a culture in itself means nothing without a rhetorical justification.

Visual rhetoric in general links between classical texts and artistic works. Forms and meanings are the main aims of visual rhetoric, which help build the skill of understanding and analysing artistic works (Marcel, 2017, p. 5). Depending on the semiotic signs included in the paintings, visual rhetoric uses the artistic structure of painting and examines the persuasive effects on the targeted audience (Ibid, p. 41). This means the analysis of the rhetorical and creative choices, such as the placement of object, the shape of the painting and its colouring, has a rhetorical message (Helmers \& Charles, 2004).

The painting is the main subject of visual rhetoric because it expresses cultural and contextual meaning if compared with the pure aesthetics (Kress et al., 1996). The visual version of rhetoric tries to upgrade the rhetorical theory to be more inclusive, wider and compressive with regard of the interpretations of the paintings (Sonja, 2016). Recently, with the existence of technology, the mass production and distribution of paintings has become quite easy (McComiskey, 2014).

In the creation of an artwork, figures of speech might be implied. An image or painting may represent the concept of 'peace' with an 'olive branch' or 'Islam' with a 'crescent' (Lioy, 2011, p. 301).

Elements in the images, such as size, colour, line and shape, are employed to imply some messages. Visual rhetoric studies how artists draw paintings to send information, where the layout and spatial positions of the elements in paintings are associated with meanings (Alex, 1996):

An image constructs its constituents according to social, political and cultural norms. Depending on the audience, the same image is possibly to refer to various rhetorical meanings. The choice and arrangement of the constituents must be employed to act some desired rhetorical effects and deliver the messages to particular societies, cultures, and audiences (Gunther, 2010, p. 26) ....

Signs may take a form of informativity with a highlitenting value to capture the watcher's attention towards the artistic works by being so deviated and rare (Ismail, 2018).

Form, medium, size and colours are all on motivate chosen (Sonja, 2016). An individual who watches the sign in the image may have no signification. It seems senseless or arbitrary. So, signs in the painting to be conceptualized as visual rhetoric should include human intervention and be displayed to the watchers for the 
purpose of communicating (ibid).

\section{Practical Analysis}

To choose a model of analysis, this study depends on the aforementioned studies concerning visual pragmatics, semiotics and cultural aspects to decode the signs embedded in the paintings selected from four Mosuli artists, with their personal permission, to conduct this study on their representations of their experiences during the three years of the so-called 'Islamic State Conquer'.

\subsection{Anwar Darweesh}

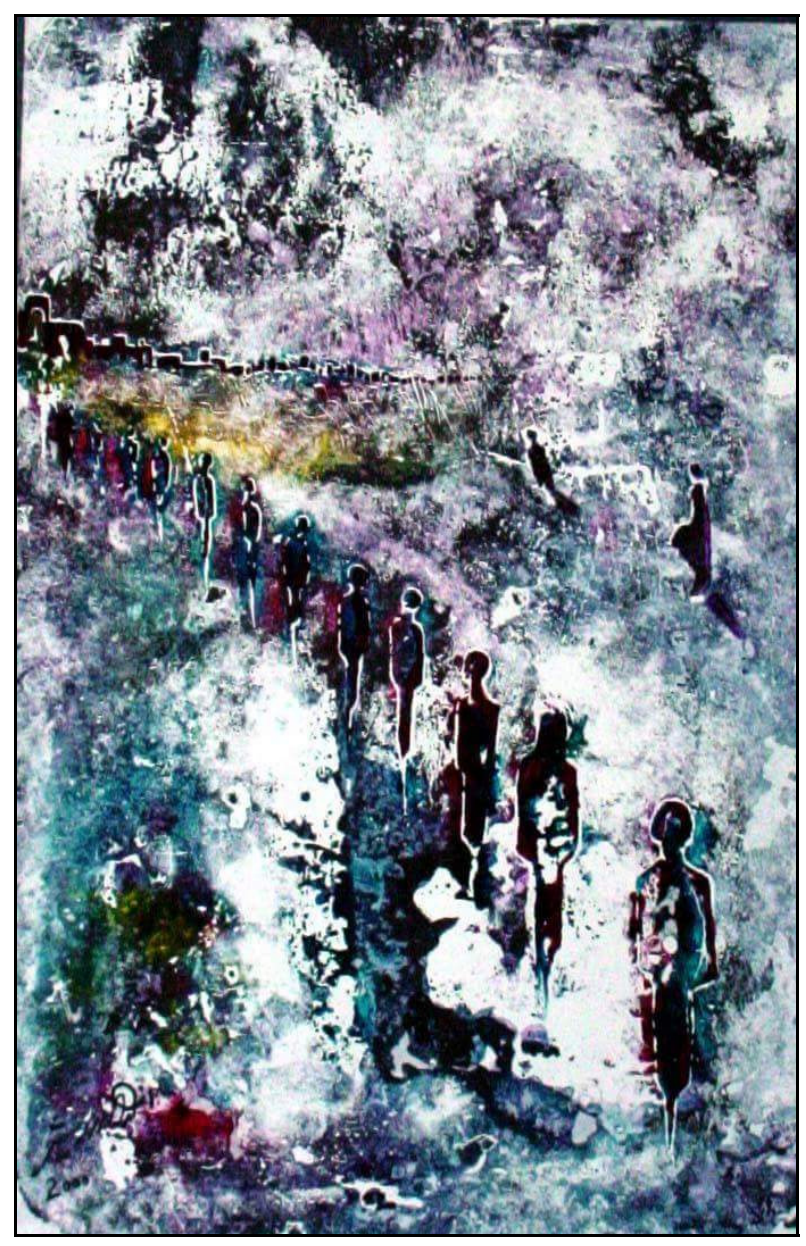

Painting 1. "The displacement" by Anwar Darweesh

\subsubsection{SL Semiotic Codes}

- People in queue

- Smoke and fire rising from the buildings

- A woman on the right looks for someone

- A young boy is looking at the burning city

3.1.2 Description and Analysis

This painting is an evident example of the effect of the period of Daesh. It has been drawn by the artist to show people's displacement during war and bombings. The interpretation is based on some clear symbols, such as the rising fire from the buildings of the city. This perspective depicts a set of tired bodies arranged in a queue. They were heading to the Iraqi Liberation Forces. The forces were looking for some suspected members of Daesh among the displaced people.

Three out of 4 teachers of translation summarized the painting's message as being only about displacement. This painting includes other signs, however, that depend on the artistic background of the translators to decode them. 
From the very beginning, the indexical sign of smoke signifies the burning and the deconstruction of the Mosuli houses.

A perspective view of the city from a distance means people are fleeing from the city and heading to refugee camps.

Another clear sign is the presence of a woman and a confused boy. The artist deliberately drew those two figures in isolation (outside the queue) to refer to their search for relatives and families who remained in the city. The two were confused, wondering whether their families' members were alive or not.

The study has examined four signs but the teachers could only interpret two, meaning that $50 \%$ of the visual message may be missing during the translation into English. This painting gives an idea that the drawer has profoundly been affected by the period of Deash and so reflects that in his works.

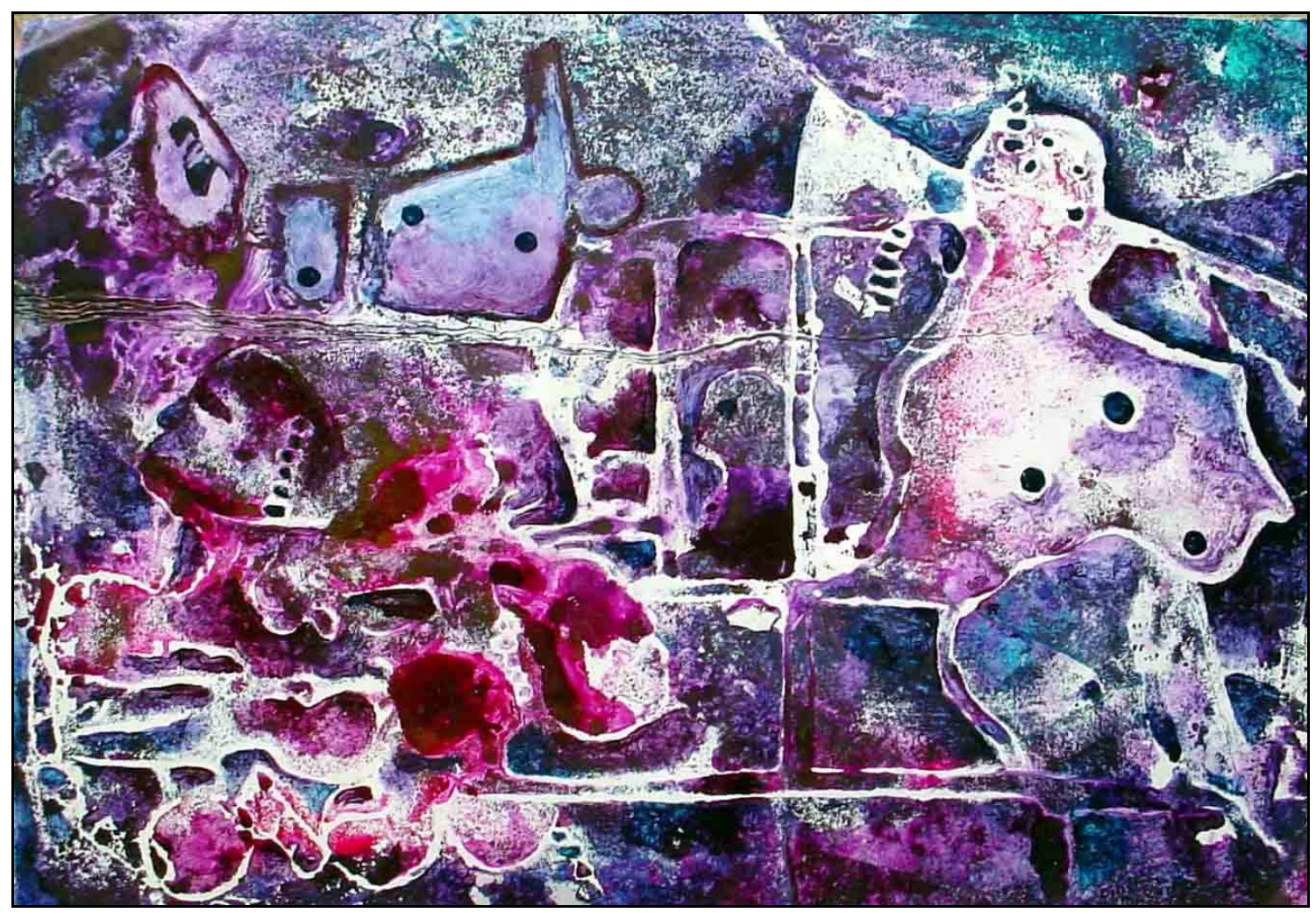

Painting 2. "The Butchery" by Anwar Darweesh

\subsubsection{SL Semiotic Codes}

- A lying man slaughtered in half

- A beheaded woman with a pearl in her ear

- A group of small cut heads: 'mass execution'

- A colour of blood; 'reddish violet', a sign of not fresh bleeding

- The mass execution mixed with the background of bricks

\subsubsection{Description and Analysis}

The artist tries to show the spectators a view of people murdered by the team of Husba, a security unit belonging to Daesh. That unit was responsible for punishing people of Mosul who criticized and refused the acts of the unit's members against the local men, women and children.

Surprisingly, most of the teachers of translation could not realize the intention or the implicature of the artist. They could only sense that the red parts meant blood. It is unfortunate that specialists in translation do not all have an artistic background. Translation is an encyclopaedic act, requiring the translator to be a real translator 
with deep-rooted thoughts about life and the culture of the source society.

This painting is very important: it depicts a brutal scene of Daesh's criminal acts. The visual rhetoric has employed 'the half-cut body' on the ground, which is an iconic sign to refer to the innocent victim. The beheaded woman is thrown on the ground; we realized she is a female victim from the pearl in her ear. In this painting, there are more than 10 holes in the picture, which might be interpreted as an emotional reflection of the drawer on the wounds and agony of the city population. The only decoded sign by the teachers of translation is the reddish violet. In fact, the artist tried to redden the ground and mix it with the violet colour to add a temporal value: when blood is old it has a violet colour.

Regarding translation, the drawer could reflect his agony during the occupation of Daesh, but the translators who lack artistic competence would be unable to transfer the visual idea and experience into English.

\subsection{Khulaif Mahmood}

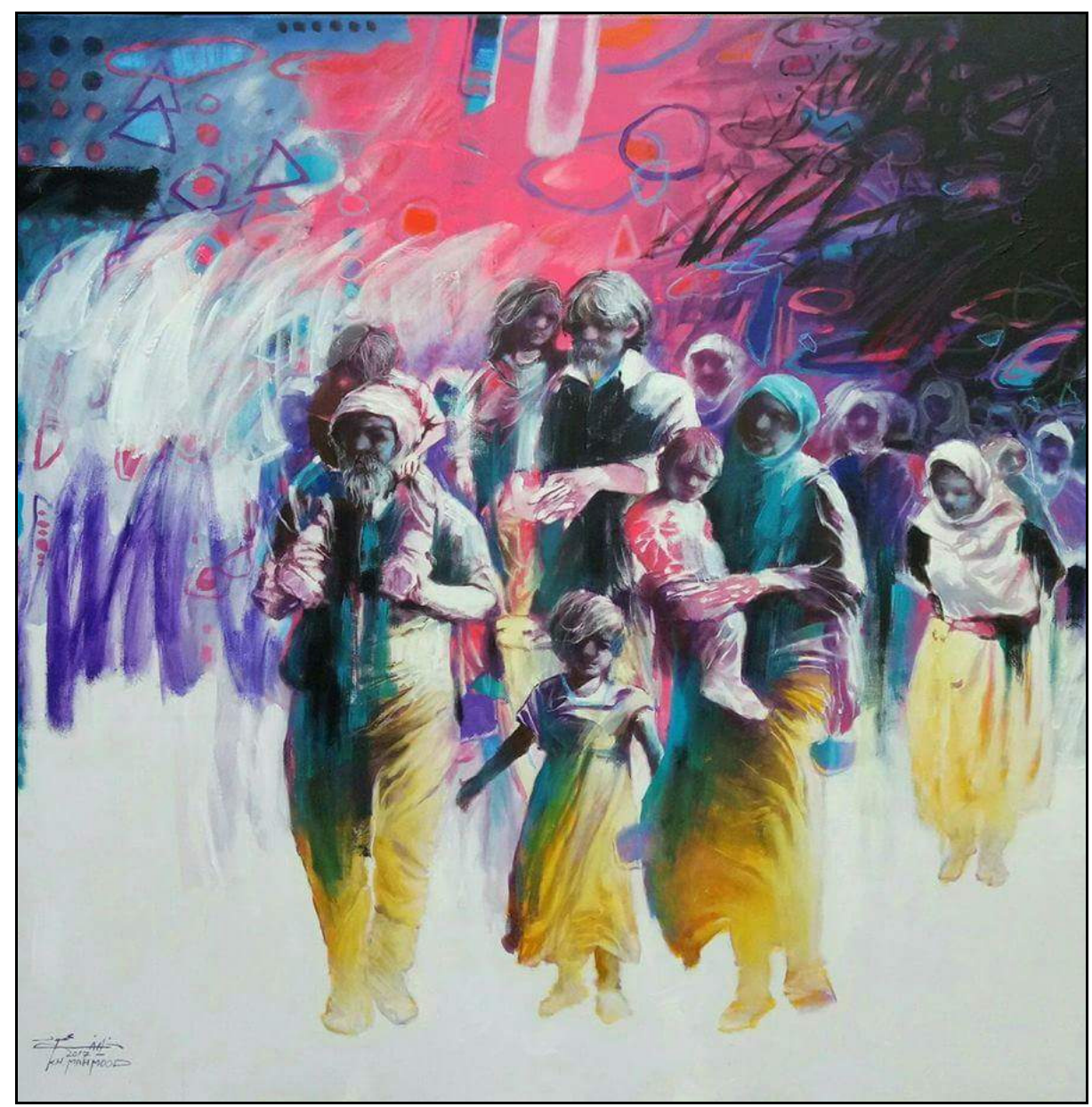

Painting 3. "Sinjar and the Ethnic Cleansing" by Khulaif Mahmood

\subsubsection{SL Semiotic Codes}

\section{- $\quad$ Fleeing Yazidis}

- Walking barefoot

- Blood red sky

\subsubsection{Description and Analysis}

This painting depicts the fleeing of the Yazidi minority from the mountain of Sinjar. This minority was the most affected one. Old men were slaughtered, and women were raped and kidnapped. It was a tragedy of abused human rights. 
These sort of images and the works done by this artist and others seem very clear. It is just like a picture (photograph); it acts as a documentary film of a period for Yazidi displacement.

With this type of drawing, the teachers of translation can master its interpretation. They interpreted this visual message very easily due to their acquaintance to the tragedy of the Yazidi people in Mosul. The translators could deliver the author's intention. The message has been visualized rhetorically into the walking barefoot people, i.e., in Arabic and Oriental cultural as those who have nothing of their property.

- Translator 1: The people here are in hurry they are powerless and running or heading to nowhere.

- Translator 2: The sky is red, which signifies that the horizon is bloody and life is a sort of blood shedding.

- Translator 3: The children or the newly born generations are living this catastrophe.

- Translator 4: The sky is full of mess; their background is black (the past), the middle of the sky is red (the present is bloody), and their future is full of puzzle and maze.

It seems that the interpretations of the teachers of translation are totally comprehensive and influential. Consequently, translation is able to convey the suffering of the tragedy within and after the period of Daesh.

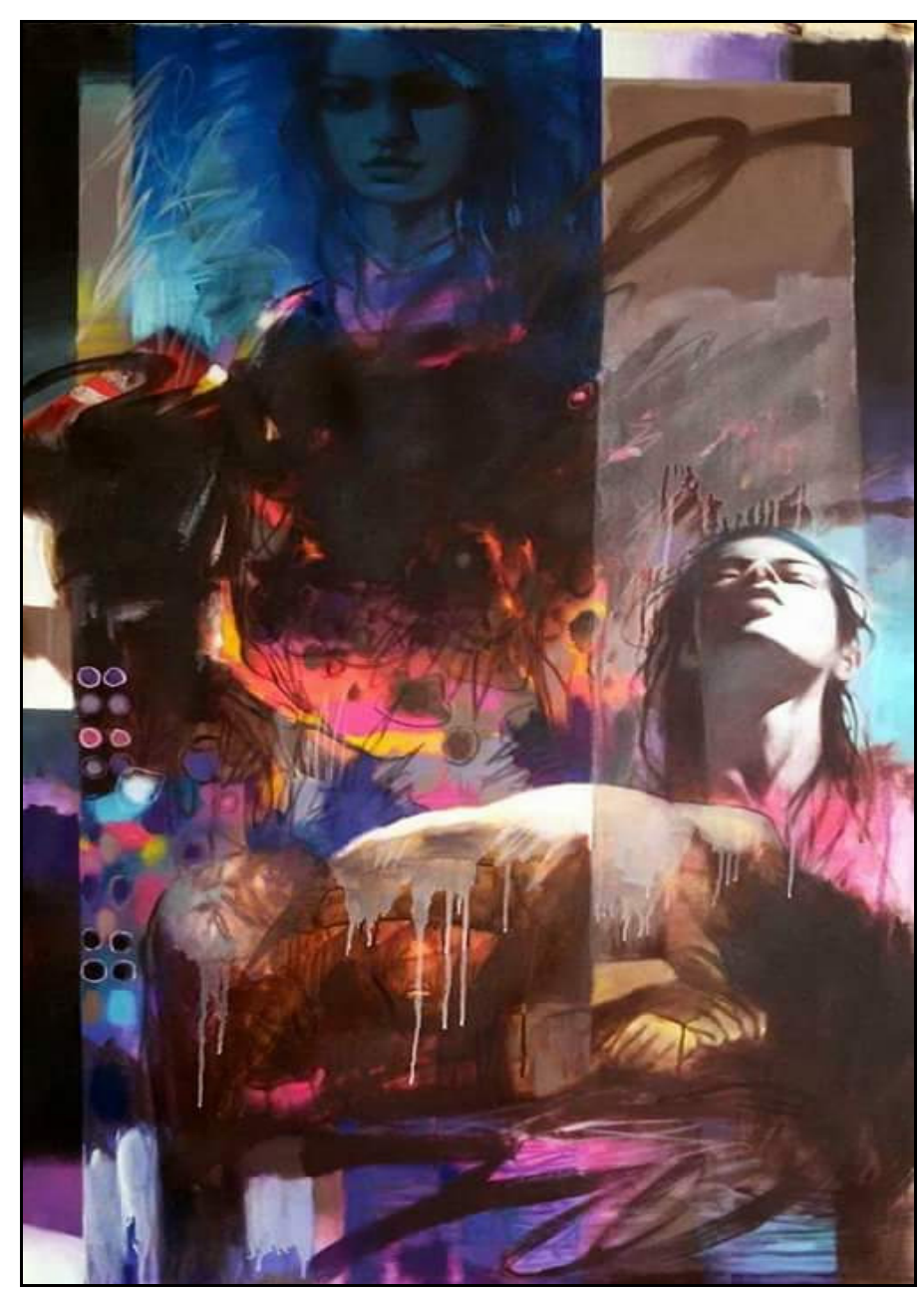

Painting 4. "Kidnapped Yazidi Girls" by Khulaif Mahmood

\subsubsection{SL Semiotic Codes}

- The face which is off-center

- The blue face in the sky

- The slaughtered man on the ground 


\subsubsection{Description and Analysis}

This painting has been drawn to depict the agony of the kidnapped Yazidi girls who suffered a lot. The artist here gives two faces for the same Yazidi girl. Each face has a different interpretation.

Those kidnapped girls were being sold and raped brutally by ISIS members.

The artist here gives footage about the life of the Yazidi girl under the capture of Daesh's members. The artist describes the kidnaped girl as the woman with a slaughtered neck; she is full of blood that covered her chest. Her head is tilted upward. The same girl has a space in the blue sky to signify that those girls are stars in the sky who have pride and dignity. The beloved is rested over the ground covered by his blood; this image has never been absent from the mind of girl victim who rejects death and thinks of dignity and love of life.

- Translator 1: A girl is crying for her killed beloved, there is always a story of love within war; this is the wisdom of life.

- Translator 2: The girl thinks of her girlfriend and she knows nothing about her. Her friend's image is imprinted in the sky.

- Translator 3: A man has been killed and sacrificed his life for the sake of his beloved. 'It is a Romeo and Juliet story, I think so!'

- Translator 4: The girl has heard that her beloved has got martyrdom in the battlefield against Daesh, and she is now trying to commit suicide.

All the above quoted interpretations are acceptable and true. Every translator draws on his own experiences and cultural background to decode such artistic codes. The drawer has accurately reflected his experience and the translators - each according to their artistic repertoire — could transfer part of the artist's visual experience.

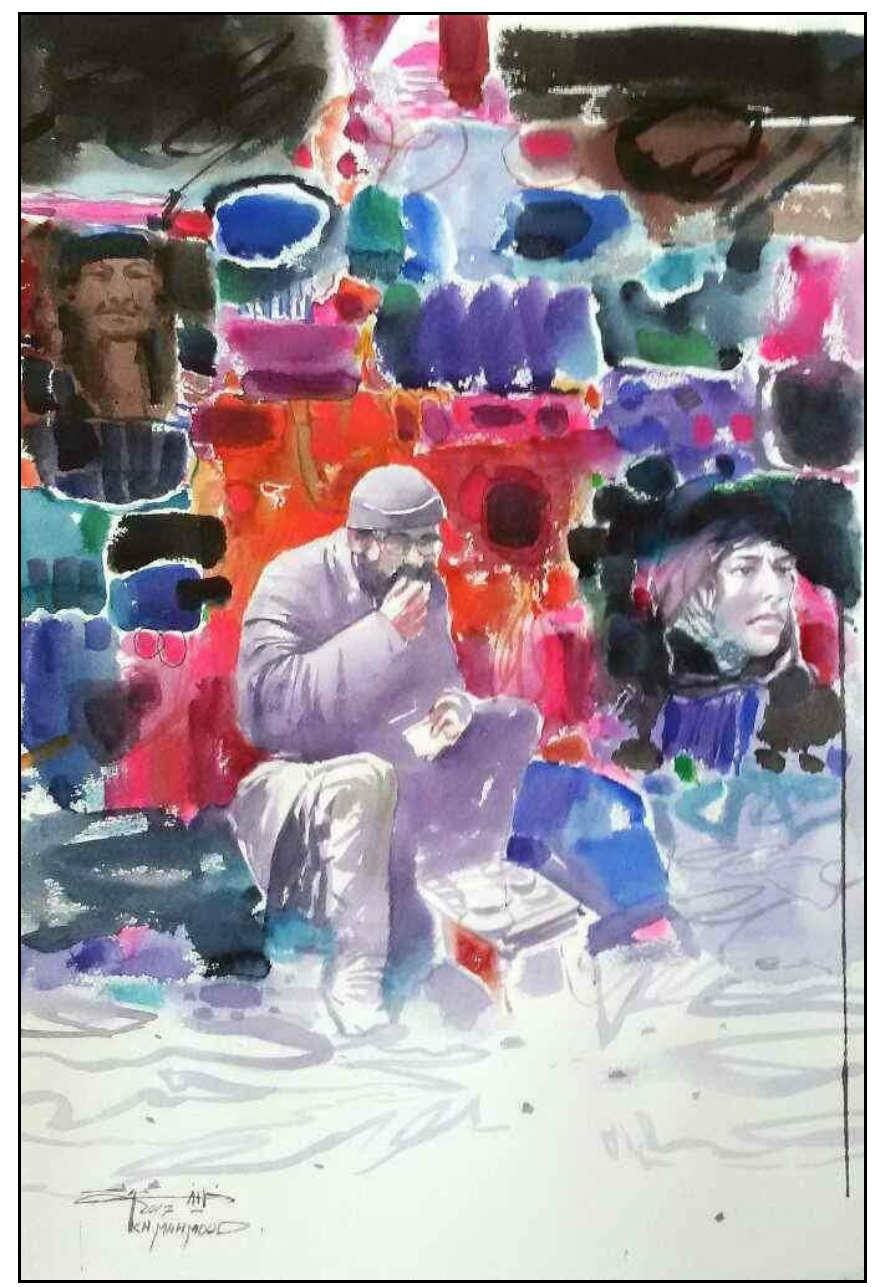

Painting 5. "Poverty and the Hell of Living" by Khuaif mahmood 


\subsubsection{SL Semiotic Codes}

- A poor and miserable man

- Afghani clothes

- Faces of two women in the imagination

- $\quad$ The empty table

\subsubsection{Description and Analysis}

A poor and miserable bearded man eating alone is the message of this painting. He thinks of some faces/his family, who were either killed or left him alone. The Afghani clothes, which was put as uniform clothes for all Mosuli men, is a sign to mean that this man is living in the period of Daesh control. He is eating 'a small piece of bread', which signifies poverty, the hell of living and being alone without a companion in life. The table is so small and empty except for a cup of water. He is eating 'Water and bread', a fairy tale in Mosuli tradition that implies poverty.

The miserable life is the message that the painter wants to send to those who want to know about the conditions throughout the period of Daesh control. It is a life full of poverty, lacking and inability.

'It is another form of slavery', translators could easily realize the message and interpret that verbally into the following:

- Translator 1: A man eats alone and asks for others to share his food. As the human nature doesn't accept the isolation, the figure who is eating in this painting is trying to gather with the faces appearing in the painting.

- Translator 2: Afghani clothes is a hidden meaning for a sign of Daesh's uniform, which means that people are under the caption of ISIS members and their forcedly practiced rules [of] 'Sharia'.

- Translator 3: Faces of disappeared figures or family member is the core of this message. Physically, I'm living alone. But, mentally those disappeared people had never been absent from my soul and mind.

- Translator 4: A labour man who is living in the period of Daesh is eating some pieces of bread. The severity of life obligated this old man to work, or I could guess he is a 'beggar' who asks from some money to manage his life and feed his children who are no longer having a mother to care for them.

It seems that the teachers of translation here are having the same message from different perspectives. All in all, the intention of the drawer has been kept.

\subsection{Atheed Tarik}

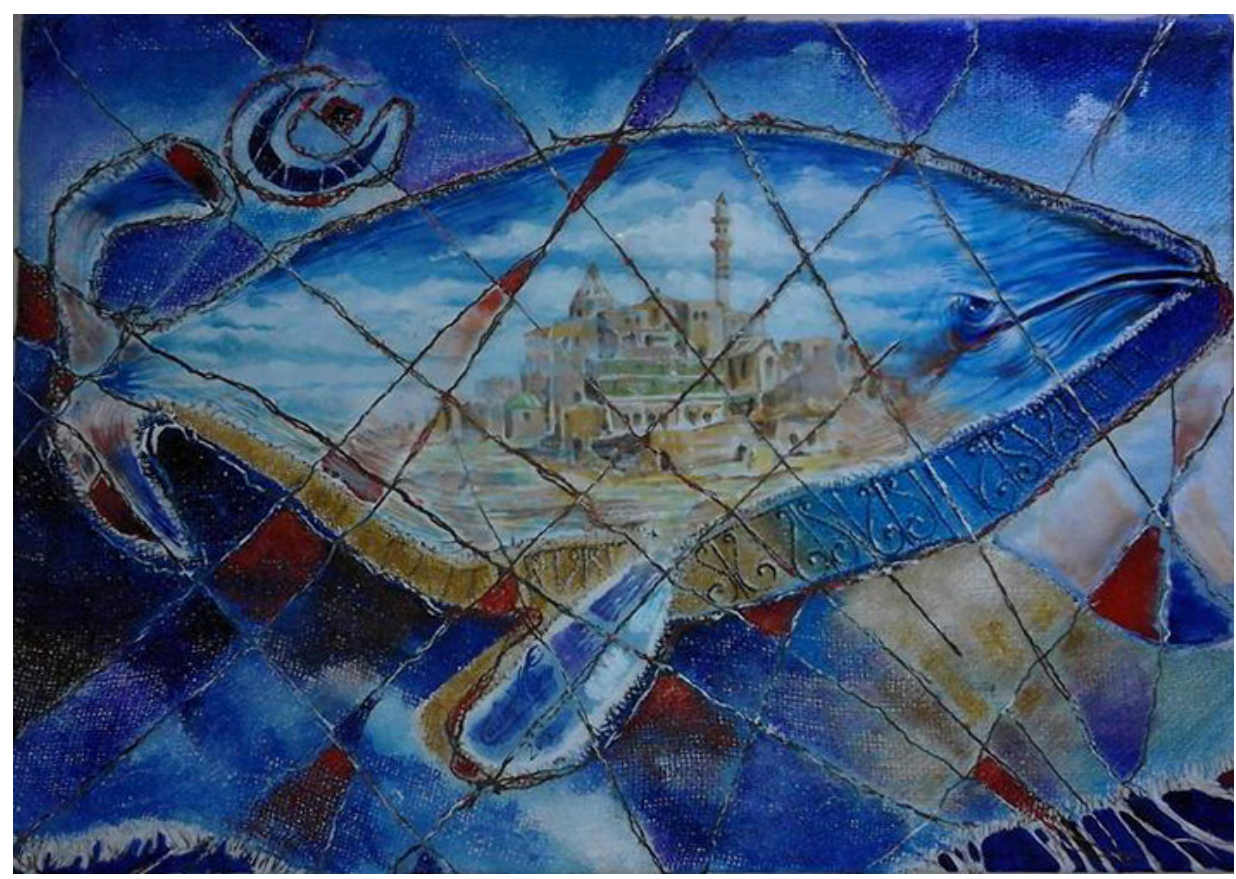

Painting 6. "Whale and Jonah" by Atheed Tarik 


\subsubsection{SL Semiotic Codes}

- The whale

- The city of Mosul is inside the whale

- The broken glass covering the painting

- The sign of ' $ن$ ' outside the whale to refer to Christianity

\subsubsection{Description}

Mosul has long been associated with the history of the prophet 'Jonah' or Yonis through the story of the whale and the swallowed man. The people believe that the grave of that prophet is located in the city of Mosul. They believe that the whale protected the prophet. So, the drawer here calls for the same whale to come back and save Mosuli people from the severe life and Daesh's abuses.

This painting is a self-appealing of history to be repeated to secure the city of Mosul from the brutality of Daesh. The whale helped the prophet Jonah according to the Islamic belief of the Mosuli population. They wanted the whale to save them and hand up their city in its abdomen from the oppression of Daesh.

- Translator 1: The whale is a sign of Mosul who protected the prophet Yonis from the disbelievers of God. Now, they are praying for the same event to help them all with their city from those disbelievers' fighters; Daesh's terrorist fighters.

- Translator 2: The drawer has broken his painting with [a] crossed line in a way that the drawer wants to give an idea that the dream of saving the city is being vanished, particularly the broken glass covering the painting is polluted by blood. It is a story of frustration and disappointment.

- Translator 3: The sign (ن- N) which refers to Christian people (Nasarah- Thiارى). ن ن sign was being imprinted on the wall of the looted Christian Mosuli residents by the members of Daesh. Thus, the drawer is saying here that the whale is the Iraqi Army and the public mobilization unties Alhashid Alsha'bi who save all the houses in Mosul.

- Translator 4: The anger whale is coming which the Iraqi people and Mosul will be saved and come back again by the desire of God and Deash will be defeated inevitably.

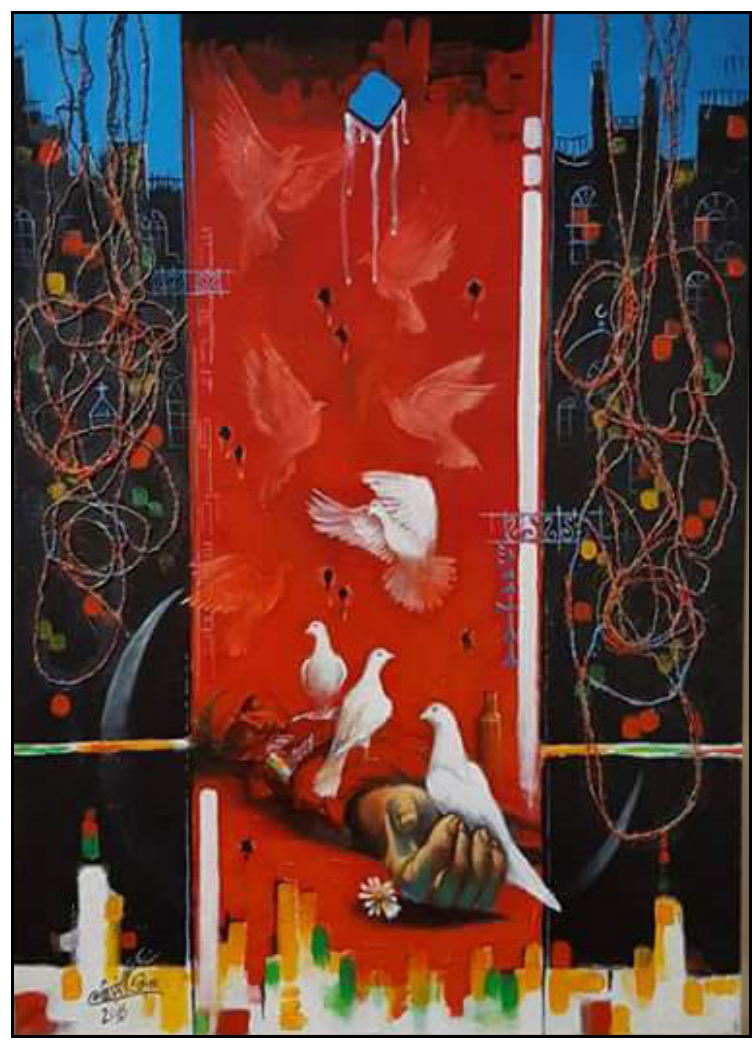

Painting 7. "Waiting for Peace" by Atheed Tarik 


\subsubsection{SL Semiotic Codes}

\section{- $\quad$ Pigeons and peace}

- Candles of the city

- Cut hand

- Bloody screen.

- The dote

\subsubsection{Description and Analysis}

The life of the city of Mosul now needs peace. In Iraqi culture the pigeon signifies peace and wish. So, Mosuli people's cut hand is extending out of the bloody wars to ask for peace and wishes. The people try to convert the ruins of their old city into candles of peace. Their hope is to stop the war of Daesh here and that no other people suffer from the brutality of ISIS. It is a very noble wish; they do not wish the hatred and destruction to be repeated with another people, even if that people were their own enemy.

The painting expresses a red background signifying the bloody sea that flooded the city. In other words, the city has been steeped in blood. The three white pigeons are here to refer to the three years of tragedy, i.e., the three years of Daesh control.

Mosul begins to move out from the hell of death towards survival. The hand waits for the peace and asks for the life that is full of love and peace. Mosulis want to make the light cover the land, and the candles to be lit for happiness after the end of that black period. That dark period in the history of Mosulis has been encoded in the black background, which people could come cross by the sea of their blood.

- Translator 1: Pigeons and peace are everything [the] people of Mosul needs after the black and bloody periods the people witnessed.

- Translator 2: The drawer wants to say that he trusts in the people of Mosul who will enlighten the ruins of the war in the old city by the candles of life.

- Translator 3: Blood is the bridge between darkness and success; People will get their peace after this sacrificing.

- Translator 4: The dot in the painting is the wish of ending terrorism; a dot is a sign of finishing. It is required to stop the robes of mass executions and to go through a new phase of life.

\subsection{Bayaat Mar'ae}

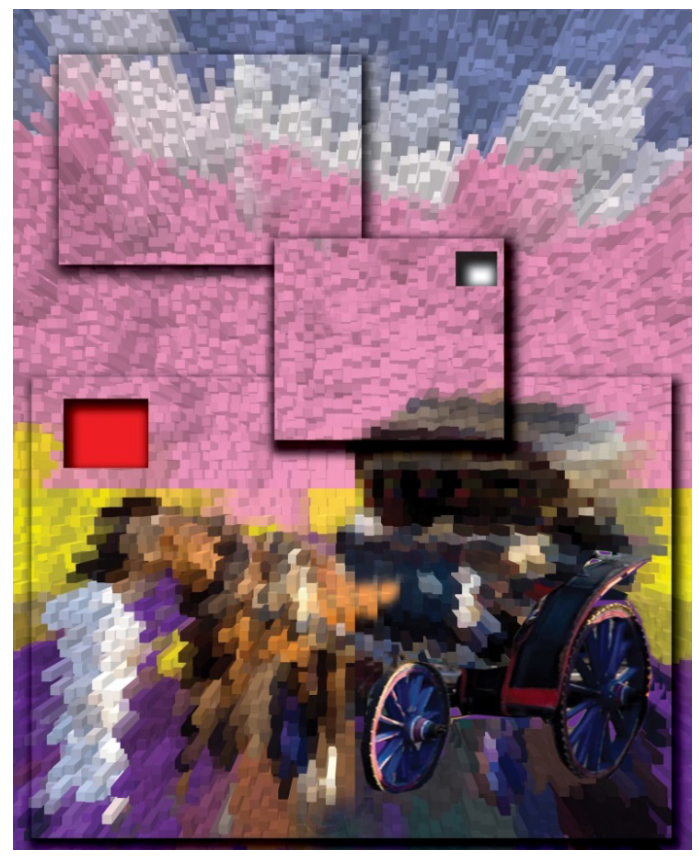

Painting 8. "Wheel of War" by Bayaat Mar'ae 


\subsubsection{SL Semiotic Codes}

- $\quad$ The broken glass

- The vehicle

- $\quad$ The red sky

- $\quad$ The victims

\subsubsection{Description and Analysis}

This painting is made according to the Cyrillic school of art. It shows a broken glass that is blowing frontward; a sign of deconstruction and blurring for the current scene of life. The drawer tries to signify the coach as a sign of life. This vehicle is life, which is full of obstacles. The vehicle is used in a way to harm the people there and to crash into them. The sky is red to refer to the massacre and crimes done by Daesh.

Ghosts are filling the painting; you cannot distinguish the people accurately whose their features have faded. Children, women and men all are under the heavy black cloud and under a horizon that is faded, expressing death and blood. In the middle of the painting, there is a wheel signifying the war, which crushes the individuals by the war's wheel.

The drawer has drawn some frames in the painting to refer to walls and sieges, i.e., society is captive and cannot be realized towards life's horizons He deliberately coloured the circumferences of these frames in black to resemble the flag of Daesh, which was black also.

- Translator 1: Life is so confused and the vehicle cannot move anymore.

- Translator 2: The sky is red and the drawer wants to say that the horizon is red which means in the Arabic culture the omen of punishment for the brutal acts done by the fighters of Daesh.

- Translator 3: The painting is a collection of squares or frames to inform the audience that the media is capturing some parts of the story. Reality is so tragic and catastrophic. The drawer was digitalizing the image, to give a hint that digital media is so defective.

- Translator 4: The victims of the wheels of Daesh are the message behind this painting. People are being crunched and killed in a hidden and blurred way away from the eyes of the international responsibility.

\section{Conclusions}

The aftermath of Daesh has become an integral psychological part of the Mosulis' life. Drawers of paintings could reflect their experiences into extra-linguistic and visual messages. They draw colours, signs of blood and war to show the world the brutality and savageness of this terrorist group.

The paintings mostly contain culturally specific issues for the source Iraqi and Mosuli society. In this case, the role of the translator arises to mediator between the source and target societies.

A painting usually includes semiotic signs with pragmatic, rhetorical and humanitarian implicature. The drawers were very skilful to document the verbal stories of the people of Mosul into visual and rhetorical scenes.

The study comes up with an important issue related to the translation process: that the translators are required to have a deep and artistic knowledge to decode the hidden meaning underlying the signs in the paintings. A translator should have an encyclopaedic and artistic repertoire.

\section{References}

Alex, P. (1996). Sign. In S. N. Robert \& S. Richard (Eds.), Critical Terms for Art History. London and Chicago: University of Chicago Press.

Brown, S. (2011). Assessing Large Groups: Engaging First Year Students. Retrieved from https://www.ucd.ie/t4cms/UCDTLT0037.ppt.pps

Byram, M., \& Risager, K. (1999). Language Teachers, Politics and Cultures. Clevedon: Multilingual Matters.

Curtin, B. (2016). Semiotics and Visual Representation. International Program in Design and Architecture (n.d.): n. pag. Web. 17 Nov. 2016.

Eco, U. (1976). A Theory of Semiotics. Bloomington: Indiana University Press. https://doi.org/10.1007/978-1-349-15849-2

Gunther. (2010). Multimodality: A Social Semiotic Approach to Contemporary Communication. London: Gunther Kress, Routledge. 
Helmers, M., \& Charles, A. (2004). Defining Visual Rhetoric. Routledge.

Ismail, A. (2018). The Role of Informativity in Translating Poetry (A Case Study of Emily Dickinson's Slant of Light). Journal of the College of Languages, 37, 90-104.

Kress et al. (1996). Reading Images: The Grammar of Visual Design. New York: Routledge.

Lioy, D. (2011). David C. Cook NIV Bible Lesson Commentary 2011-12: The Essential Study Companion for Every Disciple.

Machotka, P. (2012) Painting and Our Inner World: The Psychology of Image Making. Springer Science \& Business Media.

Manetti, G. (1993). Theories of the Sign in Classical Antiquity. Trans. Christine Richardson. Bloomington: Indiana University Press.

Marcel, D. (2017). Understanding Media Semiotics. London: Arnold.

McComiskey, B. (2014). Visual Rhetoric and the New Public Discourse. JAC: A Journal of Rhetoric, Culture, \& Politics, 24, 187-206.

Myers, D. (2002). Social Psychology. The McGraw-Hill social psychology series. McGraw-Hill.

Nicholas, A. (2011). A Quick Guide to Writing a Solid Peer Review. Eos, 92(28), 233-234. https://doi.org/10.1029/2011EO280001

Nida, E. (1995). Sociolinguistics and Translating. Retrieved from https://www.tradiling.net/eugene-nida-sociolinguistics-and-translating-v-1995/

Olk, C. (2014). Virginia Woolf and the Aesthetics of Vision. Berlin: Walter de Gruyter. https://doi.org/10.1515/9783110340235

Parmentier, J. (2014). Semiotic Degeneracy of Social Life: Prolegomenon to a Human Science of Semiosis. Semiotica, 202, 1-20. https://doi.org/10.1515/sem-2013-0095

Potts, A. (1996). Sign. Critical Terms for Art History, 17-30.

Rita, J. (2009) Human Rights and the Unborn Child. Leiden: Martinus Nijhoff.

Sonja, F. (2016). Framing the Study of Visual Rhetoric: Toward a Transformation of Rhetorical Theory. In A. H. Charles \& H. Marguerite (Eds.), Defining Visual Rhetorics (pp. 303-313). Mahwah, NJ: Lawrence Erlbaum.

\section{Copyrights}

Copyright for this article is retained by the author, with first publication rights granted to the journal.

This is an open-access article distributed under the terms and conditions of the Creative Commons Attribution license (http://creativecommons.org/licenses/by/4.0/). 